Adriana Grigorescu

National School of Political Studies and Public Administration, Bucharest, Romania

Andrea Saseanu

Academy of Economic Studies, Bucharest, Romania

\title{
Supply of the Industrial Products in Romania. A Territorial Approach
}

\section{Summary}

The industrial products and services supply was analyzed in the present paper through the statistical indicators of the industrial production, applied for Romania (2005), both at macroeconomic and regional level (on development regions).

The first part of the paper presents some of the methodological reglementations used in determining the "industrial production" statistical indicator, according to the European Union statistical practices (Pack, 2000; *** "Methodology of short-term business statistics", 2006; Peneder, 2001). In the second part of the paper, the authors analyze the main industrial policy previsions in Romania in order to accelerate the process of resource allocation among and within the various sectors, to improve the competitiveness, to attenuate the discrepancies between the economic development level of Romanian regions and to become part of a common European industrial policy. Regional analysis is a domain largely studied by Kangas, Leskinen, Kangas, 2007; Leskinen, Kangas, 2005; Rondinelli, 1996; Banai-Kashani, Reza, 1989.

\section{Theoretical Concept. Purpose of the „Industrial Production” Indicator}

Production determines the use of resources and labors and hence influences growth, income generation, and prosperity. The production index is regarded as one of the most important measures of economic activity. Developments in the industrial production index describe the economic cycles of industry, and this can be used to assess the development of GDP as a whole. This index is the reference 
indicator for economic development and it is used in particular to identify turning points in economic development at an early stage. The major advantage of the production index compared with other indicators is its combination of fast availability (relative to GDP for example) and at the same times its detailed activity breakdown.

European Union statistic regulations require short-term statistics on production. The production index is also known as an output index or a production volume index. In fact, the theoretical purpose of the index is not to reflect production but value added. In practice, however the index is not referred to as a value added index, very few national statistical authorities produce an index using value added, and they rely instead mainly on production or turnover data. This index is referred to as the IPI (industrial production index).

The purpose of the IPI is to measure normally on a monthly basis the price change- adjusted own-output of a branch (and the total for industry). Monthly measurement is common in order to detect changes in economic developments at the earliest possible stage. Only an up-to-date index is suitable for short-term observation of economic developments. The IPI aims to identify volume changes in output.

Values are affected by volume and price changes. Whenever values are used to compile the production index, they must be adjusted by removing pure inflationary price changes in order to isolate pure volume development (including quality changes). The branches own output should be measured. In other words, there is a shift from a gross to a net analysis of output (from production value to value added). All the inputs that are not produced by the observation unit itself but are obtained or purchased from other units (and hence make up intermediate consumption) must be deducted from the unit's gross output. This ensures that the output of a branch (and the total for industry) is presented without double counting and irrespective of changes in vertical integration.

\section{Definition and Reference Period}

The theoretical aim of the IPI is to reflect developments in value added. Value added at basic prices can be calculated from turnover (excluding VAT and other similar deductible taxes directly linked to turnover), plus capitalized production, plus other operating income plus or minus the changes in stocks, minus the purchases of goods and services, minus taxes on products which are linked to turnover but not deductible plus any subsidies on products received.

Income and expenditure classified as financial or extraordinary in company accounts is excluded from value added. Hence, subsidies on products are included in value added at basic prices, whereas all taxes on products are excluded.

Value-added is calculated "gross" as value adjustments (such as depreciation) are not subtracted. Dependent on the method used to compile the index, account should be taken of: 
- variations in type and quality of the commodities and of the input materials,

- changes in stocks of finished goods and work in progress on goods and services,

- changes in technical input-output relations (processing techniques),

- related services, such as the assembling of production units, mounting, installations, repairs, planning, engineering, creation of software.

\section{Data Collecting. Difficulties with the Theoretical Concept}

The greatest difficulty in defining a production index is finding a useful measure of economic activity and measuring it in a way that is as precise and up-to-date as possible. In economic terms, the most appropriate measure of the activity of an observation unit or a branch is value added. The concept of an ideal IPI follows this approach. This theoretical requirement - short-term measuring of the development of value added - justifies, at a conceptual level, the use of the IPI as a short-term variable in assessing the development of GDP in volume terms. In practice, however, value added is not available on a monthly basis in most countries. Therefore data is generally collected for variables other than value added in order to compile the IPI. Given the difficulties with the theoretical concept of the IPI, it is unsurprising that there are many ways that it can be compiled. In general, it is impossible to say that one approach is better than another is as the choice depends largely on the specific situation in a branch, and may differ from country to country. In every case, the key is to develop a "good" economic indicator of the business cycle. Possible alternatives for the compilation of an IPI are: (gross) output quantities, gross production value, turnover, raw material consumption, labor input and energy use.

The choice of basic information is a complex task and of fundamental importance for the quality of IPI. The decision depends on numerous factors, so it is difficult to make general recommendations; the expertise and experience of survey statisticians are crucial along with professional advice from the business community or their representatives.

The term production can be used to describe the production process and it can be used for the results (gross output) of the production process, in other words the products (goods and services). The key variable in terms of resource consumption, the use of labor and income generation is the production process. In practice production process data cannot be collected and so the analysis is restricted to gross outputs and, to some extent, the input factors.

In industry, the outputs are the goods produced, as well as the directly related industrial services (for example assembly, maintenance). In the case that outputs are used the decision as to precisely which measure / definition of gross output is selected as the basis of an IPI largely depends on three factors: 
- the gross output should be recorded as precisely as possible and should be representative of the economic development in the branch concerned,

- the data should be as up-to-date as possible,

- the costs (for companies and statistical offices) of recording the statistical data should be borne in mind.

\section{Measurement Possibilities}

The basic compilation of an IPI is described using the value of gross production as the basic information. However, this does not imply that this method is preferred. The IPI compiled in this way is essentially a gross output index. The IPI - at least at the level of the individual branches - is a measure of the development of the volume of gross output, which is a key economic variable in itself. Only with the aggregation of the IPI across branches does the net aspect play a part using value added data for weighting. It is important to be aware of both the conceptual and the theoretical approach, in other words the theoretical IPI as an index of value added (net output), and the practical outcome, in other words the IPI mainly as a gross output index.

The most accurate production information on products is obtained from specialized surveys on output. In the EU Member States the Prodcom survey is carried out annually. The Prodcom list describes between 5,000 and 6,000 products and/or product categories. To calculate an IPI, however, sub-annual and preferably monthly production information is required. For this reason, the best theoretical basis for an IPI is a representative monthly production survey. A question might arise if quantities or value of products should be used to compile the index. At first, output quantities would appear to be most suitable (for example number of items, kg, litres) in order to track the development of production. However, this only applies to very homogeneous products. In cases where there are significant quality differences or heterogeneous products (for example high-technology machinery, personal computers or cars), declared values are the suitable observation variable. Here, the use of suitable price deflators must ensure that the quality component is reflected in the production volume. The precise definition of production to be used in a survey of outputs must also be clarified. The Prodcom-Regulation differentiates between sold production, production intended for sale and total production. The appropriate variable for an IPI is total production, since the entire economic activity of the unit is to be measured. Total production is the sum of production intended for sale and production for further processing within the same unit. It should be noted however that there might well be problems collecting data on total production as this information may not be easily available within an observation unit's records. 
Measures of production are:

Total production $=$ production for sale + production for further processing; Production for sale - net increase in stocks of finished goods and work in progress $=$ production sold .

Looking at the part of total production concerning production intended for sale, for the IPI it makes no difference whether the production is initially stored by the observation unit or is sold immediately (within the same reference period that it was produced). The difference between sold production and production intended for sale is significant as these two values are separated by the storage interval.

Looking at the other part of total production, namely production for further processing within the same observation unit, if this plays an important role within a particular branch, it must also be adequately reflected in the IPI. The value for total production can be estimated by multiplying the amount (quantity) for further processing with percentage of total production, is very small, the uncertain basis for the average value of sold production could give rise to implausible results; in these cases, it may be appropriate to compile the IPI by using quantities of total production instead of values.

\section{Sampling}

As the aim of the indicator is to show in a representative manner, the short-term development of individual branches and of industry as a whole, it is not necessary to include all products and / or all observation units. Rather, a selection of products and / or units can take place. The quality of the selection can be verified based on a comprehensive production survey which takes place at least once a year. It must also be ensured that the selection does not become too outdated and that actual structural changes and technical progress are reflected in the IPI.

\section{Alternative Methods/Variables in Computing the Industrial Indicator}

Untill now it was described the collection of data for compiling the IPI based on gross production values. In fact, as previously noted, a range of options for compiling the IPI is available. These are based on different output or input variables. The most suitable variable depends on the specific situation in a branch and the basic conditions (availability of statistical data) in a country. Therefore, it is not unusual for different types of basic information to be used in parallel in any given country, and for differences to exist between countries in the type of basic information used for any given branch. 
The output quantity is at first sight the most obvious variable to use in order to construct an IPI (in the sense of an output index). However, as already noted, this is only true in the case of homogeneous products. The more heterogeneous the products, the more problematic it is to aggregate the quantities for individual products to product groups. In these cases, updating with gross production values (as already described) is preferred. A further problem in practice is the choice of the correct physical unit (for example number of items, weight, volume, surface, length). Here, it should be examined which series correlates most closely with the development of value added.

Changes in the quality of a good over time must also be taken into account. It is a major problem that it is not possible to say in which way quality changes will influence the change in quantity from one period to the next as quality changes may influence the quantity produced in different ways. In the case of significant quality changes, the only option is to form a new series for the different qualities of the product. When compiling using production values, this quality difference is reflected in the development of the value of production and is taken into account by deflating with price indices that show pure inflationary developments only.

The major advantage of using quantities as the basic information is that quantity relatives are obtained in the first stage of index computation. The appropriate variable for observation of the output quantities is the quantity of total production - thus the sum of production for sale and production intended for further processing in the same observation unit.

In Romania, the official version of „List of industrial products and services PRODCOM" (used in collecting data about industrial production in European Union member countries) is called the nomenclature of industrial products and services PRODROM.

According to the methodology of National Institute of Statistics in Romania, industrial production represents the value of manufactured finished products, delivered or which are to be delivered, semifabs delivered from own production, the value of processing of the customers raw materials and materials, Works (services) of industrial nature rendered to third parties, immobilized production, as well as the stocks balance of finite products semifabs and unfinished production.

Physical output includes total manufactured quantities (including those obtained and consumed within the same enterprise). In case of the products expressed in terms of value, data are presented in current prices of respective period. Beginning with 2001, statistical survey on industrial physical output addresses economic operators having industry as their primary and/or secondary activity. The surveyed enterprises cover $90 \%$ of total turnover within each industrial activity (CANE Rev. 1 division level). According to enterprises concentration within each industrial activity, the following enterprises were included in the survey:

a) over 9 employees (CANE Rev.1, divisions: 14, 15, 17-20, 22, 24-30, 32, 33, $36,37)$; 
b) over 19 employees (CANE Rev.1, divisions: 10-13, 16, 21, 23, 31, 34, 35, 40, 41).

Studying the Romania's production of the main industrial products (2005 year) and its composition on different development regions, we concluded to the following results (table 1):

- Almost 90\% of mined coal production in Romania was produced in South-West Region (86,54\%); the rest of it, of almost $10 \%$ represents the coal mined from Western Region (9,8\%);

- Almost half of crude oil production was extracted, in 2005, from the South Region (more precisely 44\%), followed at a large distance by the SouthEast region and by the South-West region (with approximately equal shares: $15 \%$ ); The South Region supplies over $2 / 3$ of Romania's production of gasoline, Diesel oil and fuel oil;

- Over $40 \%$ of natural gases production was extracted from the Central Region of the country $(41,75 \%)$ and over a quarter - from the South-west Region;

- Almost half of textile production in 2005 was produced by two regions: the North-East one, and the South one, with equal shares; the third place belongs to Bucharest-Ilfov region (over 17\% of the total textile production);

- Almost 50\% of the footwear production was manufactured in the Western Region and in the North-West region (with approximately equal shares); in Bucharest-Ilfov region, it was produced $1 / 5$ of the total footwear production;

- Wooden territories from the Central Region represented the base for manufacturing almost $40 \%$ of the total timber Romanian production in 2005 year. This region is followed by the North-East region (with over a quarter of total production);

- North-East region produced in 2005 year almost 30\% from the total paper production; Central region and South-West region had, too, significant contributions (18\%, respectively 15\%), followed by the South East region (14\%);

- A powerful chemical industry, developed in the South region and in Central region represented the main tool in obtaining over $2 / 3$ of the chemical fertilizers production; in Bucharest it was produced over $16 \%$ of the total production;

- In the South-East region it was manufactured a $1 / 3$ of total cement production of Romania, and in South Region - a quarter of it;

- Over $70 \%$ of the total steel production in Romania was manufactured in South-East region, followed at a large distance, by Western region (14\%);

- In Romania furniture products are manufactured in many regions of the country ; the most significant contributions belong to the North-west region $(22,68 \%)$, Central region $(18,21 \%)$ and in Western region $(15,27 \%)$;

- South Region is the main producer of meat and meat products (about 30\%);

- In South-East region it was produced over 35\% of edible oils production, and in North-East region - a quarter of the total production; 
- The main manufacturing region of consumption milk and cheese products is the Central region (31,44\% - for milk and 45,74\% - for cheese). It is followed by the North-East region (24,63\% - for milk, and 15,2\% - for cheese).Over half of total sugar production was manufactured in NorthEast region. Bucharest is situated on one of the last places, regarding the mentioned categories of food production.

Table 1. The share of physical production on the main industrial products, on development regions, in Romania, 2005 (\%)

\begin{tabular}{|c|c|c|c|c|c|c|c|c|c|c|}
\hline $\begin{array}{l}\text { Development } \\
\text { regions }\end{array}$ & $\begin{array}{c}\text { Chemi- } \\
\text { cal } \\
\text { fertili- } \\
\text { zers } \\
(\%)\end{array}$ & $\begin{array}{c}\text { Ce- } \\
\text { ment } \\
(\%)\end{array}$ & $\begin{array}{c}\text { Crude } \\
\text { steel } \\
(\%)\end{array}$ & $\begin{array}{c}\text { Furni- } \\
\text { ture } \\
(\%)\end{array}$ & $\begin{array}{l}\text { Meat } \\
(\%)\end{array}$ & $\begin{array}{c}\text { Meat } \\
\text { pro- } \\
\text { ducts } \\
(\%)\end{array}$ & $\begin{array}{c}\text { Ea- } \\
\text { table } \\
\text { oils } \\
(\%)\end{array}$ & \begin{tabular}{|c|} 
Con- \\
sump- \\
tion \\
milk \\
$(\%)$ \\
\end{tabular} & \begin{tabular}{|c|} 
Che- \\
ese \\
pro- \\
ducts \\
$(\%)$
\end{tabular} & $\begin{array}{c}\text { Sugar } \\
(\%)\end{array}$ \\
\hline North-East & 9.73 & 9.88 & 0.13 & 11.71 & 14.84 & 9.47 & 25.90 & 24.63 & 15.20 & 20.94 \\
\hline South-East & 0.24 & 32.99 & 71.96 & 8.66 & 13.81 & 13.29 & 35.62 & 7.32 & 2.57 & 54.78 \\
\hline South & 33.77 & 26.25 & 8.06 & 10.78 & 28.26 & 30.75 & 13.53 & 7.82 & 6.84 & 6.31 \\
\hline South-West & 5.81 & 5.58 & 0.74 & 4.22 & 4.81 & 4.04 & 8.01 & 1.89 & 1.45 & 5.40 \\
\hline West & 0.00 & 9.61 & 14.15 & 15.27 & 9.49 & 6.91 & 0.00 & 5.61 & 1.02 & 0.00 \\
\hline North-West & 0.00 & 15.63 & 4.52 & 22.68 & 8.98 & 11.43 & 12.92 & 20.85 & 26.50 & 8.10 \\
\hline Central & 33.62 & 0.00 & 0.13 & 18.21 & 16.31 & 14.08 & 0.00 & 31.44 & 45.74 & 4.47 \\
\hline Bucharest-Ilfov & 16.83 & 0.06 & 0.30 & 8.47 & 3.50 & 10.02 & 4.02 & 0.45 & 0.67 & 0.00 \\
\hline Total & 100.00 & 100.00 & 100.00 & 100.00 & 100.00 & \begin{tabular}{|l|l}
100.00 & 1 \\
\end{tabular} & 100.00 & 100.00 & 100.00 & 100.00 \\
\hline $\begin{array}{c}\text { Development } \\
\text { regions }\end{array}$ & $\begin{array}{c}\text { Mined } \\
\text { coal } \\
(\%)\end{array}$ & $\begin{array}{c}\text { Crude } \\
\text { oil ex- } \\
\text { tracted } \\
(\%)\end{array}$ & $\begin{array}{c}\text { Natural } \\
\text { ex- } \\
\text { tracted } \\
\text { gases } \\
(\%)\end{array}$ & $\begin{array}{l}\text { Fabrics, } \\
\text { exclu- } \\
\text { sive } \\
\text { silk (\%) }\end{array}$ & \begin{tabular}{c|c} 
Foot- \\
wear \\
$(\%)$
\end{tabular} & $\begin{array}{c}\text { Timber } \\
(\%)\end{array}$ & $\begin{array}{c}\text { Paper } \\
(\%)\end{array}$ & $\begin{array}{c}\text { Gaso- } \\
\text { line } \\
(\%)\end{array}$ & $\begin{array}{c}\text { Diesel } \\
\text { oil } \\
(\%)\end{array}$ & $\begin{array}{c}\text { Fuel } \\
\text { oil } \\
(\%)\end{array}$ \\
\hline North-East & 0.05 & 8.99 & 3.82 & 26.46 & \begin{tabular}{l|l}
6 & 10.20 \\
\end{tabular} & \begin{tabular}{l|l|} 
& 26.57 \\
\end{tabular} & \begin{tabular}{|l|}
78.08 \\
\end{tabular} & 13.01 & 15.47 & 16.51 \\
\hline South-East & 0.00 & 16.67 & 15.42 & 2.98 & 1.90 & 5.47 & \begin{tabular}{l|l}
74.20 \\
\end{tabular} & 20.30 & 25.86 & 8.46 \\
\hline South & 2.38 & 44.09 & 7.83 & 23.87 & 3.15 & 4.78 & \begin{tabular}{l|l}
3 & 12.64 \\
\end{tabular} & 66.69 & 58.63 & 72.28 \\
\hline South-West & 86.54 & 14.72 & 25.94 & 10.94 & 1.92 & 2.52 & \begin{tabular}{l|l}
2 & 15.25 \\
\end{tabular} & 0.00 & 0.00 & 0.00 \\
\hline West & 9.80 & 5.42 & 1.52 & 1.96 & \begin{tabular}{l|l}
6 & 24.30 \\
\end{tabular} & 5.68 & 0.00 & 0.00 & 0.00 & 0.00 \\
\hline North-West & 0.36 & 9.27 & 3.66 & 2.69 & \begin{tabular}{l|l}
9 & 24.66 \\
\end{tabular} & 12.41 & \begin{tabular}{l|l}
11.28 \\
\end{tabular} & 0.00 & 0.05 & 2.74 \\
\hline Central & 0.87 & 0.15 & 41.75 & 13.89 & \begin{tabular}{l|l}
9 & 13.94 \\
\end{tabular} & \begin{tabular}{l|l|}
4 & 39.42 \\
\end{tabular} & \begin{tabular}{l|l}
2 & 18.06 \\
\end{tabular} & 0.00 & 0.00 & 0.01 \\
\hline Bucharest-Ilfov & 0.00 & 0.68 & 0.06 & 17.21 & $1 \quad 19.92$ & 3.16 & 0.49 & 0.00 & 0.00 & 0.00 \\
\hline Total & 100.00 & 100.00 & 100.00 & 100.00 & \begin{tabular}{l|l}
0 & 100.00 \\
\end{tabular} & 100.00 & 100.00 & 100.00 & 100.00 & 100.00 \\
\hline
\end{tabular}

Analyzing which development region of Romania contributes more significant to the total industrial production, they were ranked using as ranking criteria the share of industrial production on types, categories of industrial products. We used the relative distances method, compared to the maximum performance unit. 
The ranking criteria were expressed in a relative form, as structural (relative) indicators. They are computed in a $\frac{\text { part }}{\text { whole }}$ way, illustrating the statistical population composition by the studied variable. They are also named as weights, and computed according to the following relation:

$$
g_{i}^{x}=\frac{x_{i}}{\sum_{i=1}^{n} x_{i}} \quad \text { (expressed in coefficients), }
$$

or:

$$
g_{i \%^{x}}^{x}=\frac{x_{i}}{\sum_{i=1}^{n} x_{i}} \cdot 100 . \quad \text { (expressed in per cents) }
$$

Weights show the share of one variables' level (X) registered at a statistical unit or group of units " $i$ " $\left(x_{i}\right)$ in the total level of the variable $\left(\sum_{i=1}^{n} x_{i}\right)$. This relation can be computed only if the individual variables' levels can be summed.

The relative distance from the maximum performance method removes some of the ranges' method disadvantages, obtaining a clearer hierarchy of the territorial units. For each hierarchy criteria, we compute the relative distance of every territorial unit from the maximum level one. The relative distance is expressed by coordination-indicators whose values are less than 1 , according to the relation:

$$
d_{i}^{X j}=\frac{x_{i}^{j}}{\max \left\{x_{i}^{j}, i=\overline{1, n}\right\}} \quad \text { with } \quad i=\overline{1, n} ; \quad j=\overline{1, m} ;
$$

where: $d_{i}^{X j}$ represents the relative distance computed for the " $i$ " statistical unit and $X_{j}$, variable, and max $\left\{x_{i}^{j}, i=\overline{1, n}\right\}$ is the maximum value of $X_{j}$ variable, of all " $n$ " statistical units.

We then compute the geometrical average of the coordination indicators, expressing the average distance at which a certain territorial-unit is situated, from a hypothetical one, according to the following relation:

$$
\bar{d}_{i}=\sqrt[m]{\prod_{j=1}^{m} d_{i}^{X j}}, \quad i=\overline{1, n}
$$

where: $\bar{d}_{i}$ represents the average relative distance computed for the " $i$ " statistical unit. 
The hypothetical unit is the one that obtains the maximum performance for all the criteria in the same time. According to the range of average relative distances obtained above, each territorial unit gets a final rank ( 1 - for the territorial unit with the highest average relative distance, and $n$ for the one with the lowest value). By dividing the average relative distance of each region to the most performing one, we get the relative position of the respective territorial unit compared to the most performing unit, according to the relation:

$$
\operatorname{Poz}_{i}^{\%}=\frac{\bar{d}_{i}}{\max \left\{\bar{d}_{i}, i=1, n\right\}} \cdot 100 .
$$

We can see the results of application method in table 2. The South region is placed in the top of the list, having the most significant contribution to manufacturing the industrial production in Romania (first rank), followed by the Central region (second rank), which accomplished almost $80 \%$ of the first region's performance. On the last two places were situated Bucharest-Ilfov region ( 8 rank) proceeded by the Western region (7 rank).

Table 2. The application results of the relative distance from the maximum performance method

\begin{tabular}{|c|c|c|c|c|c|c|c|c|c|c|c|c|c|}
\hline \multirow[b]{2}{*}{$\begin{array}{l}\text { Development } \\
\text { regions }\end{array}$} & \multicolumn{10}{|c|}{ Relative distances for: } & \multirow[b]{2}{*}{ 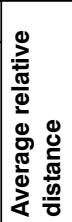 } & \multirow[b]{2}{*}{ 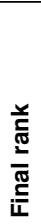 } & \multirow{2}{*}{ 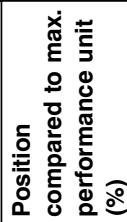 } \\
\hline & 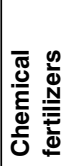 & Е & 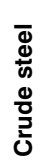 & $\begin{array}{l}\text { 올 } \\
\stackrel{2}{\frac{3}{2}} \\
\text { 논 }\end{array}$ & 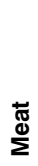 & 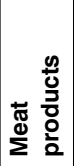 & 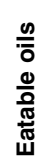 & 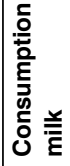 & 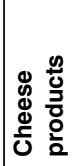 & 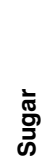 & & & \\
\hline North-East & 4 & 4 & 7,5 & 4 & 3 & 6 & 2 & 2 & 3 & 2 & 0,41 & 3 & 75 \\
\hline South-East & 6 & 1 & 1 & 6 & 4 & 3 & 1 & 5 & 5 & 1 & 0,40 & 4 & 73 \\
\hline South & 1 & 2 & 3 & 5 & 1 & 1 & 3 & 4 & 4 & 4 & 0,55 & 1 & 100 \\
\hline South-West & 5 & 6 & 5 & 8 & 7 & 8 & 5 & 8 & 6 & 5 & 0,22 & 6 & 39 \\
\hline West & 7,5 & 5 & 2 & 3 & 5 & 7 & 7,5 & 6 & 7 & 7,5 & 0,17 & 7 & 31 \\
\hline North-West & 7,5 & 3 & 4 & 1 & 6 & 4 & 4 & 3 & 2 & 3 & 0,31 & 5 & 56 \\
\hline Central & 2 & 8 & 7,5 & 2 & 2 & 2 & 7,5 & 1 & 1 & 6 & 0,43 & 2 & 79 \\
\hline Bucha-rest-Ilfov & 3 & 7 & 6 & 7 & 8 & 5 & 6 & 8 & 8 & 7,5 & 0,15 & 8 & 28 \\
\hline
\end{tabular}

\begin{tabular}{|c|c|c|c|c|c|c|c|c|c|c|}
\hline \multirow[b]{2}{*}{$\begin{array}{l}\text { Development } \\
\text { regions }\end{array}$} & \multicolumn{10}{|c|}{ Relative distances for: } \\
\hline & 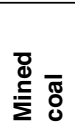 & 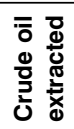 & 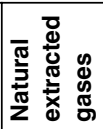 & 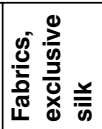 & 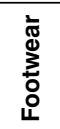 & 高 & 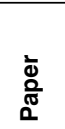 & 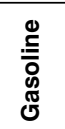 & $\begin{array}{l}\overline{\overline{0}} \\
\bar{\Phi} \\
\Phi \\
\overline{0}\end{array}$ & $\frac{\overline{\overline{0}}}{\frac{\Phi}{2}}$ \\
\hline North-East & 0,00 & 0,20 & 0,09 & 1,00 & 0,41 & 0,67 & 1,00 & 0,20 & 0,26 & 0,23 \\
\hline South-East & 0,00 & 0,38 & 0,37 & 0,11 & 0,08 & 0,14 & 0,51 & 0,30 & 0,44 & 0,12 \\
\hline South & 0,03 & 1,00 & 0,19 & 0,90 & 0,13 & 0,12 & 0,45 & 1,00 & 1,00 & 1,00 \\
\hline South-West & 1,00 & 0,33 & 0,62 & 0,41 & 0,08 & 0,06 & 0,54 & 0,00 & 0,00 & 0,00 \\
\hline West & 0,11 & 0,12 & 0,04 & 0,07 & 0,99 & 0,14 & 0,00 & 0,00 & 0,00 & 0,00 \\
\hline North-West & 0,00 & 0,21 & 0,09 & 0,10 & 1,00 & 0,31 & 0,40 & 0,00 & 0,00 & 0,04 \\
\hline Central & 0,01 & 0,00 & 1,00 & 0,52 & 0,57 & 1,00 & 0,64 & 0,00 & 0,00 & 0,00 \\
\hline Bucharest-Ilfov & 0,00 & 0,02 & 0,00 & 0,65 & 0,81 & 0,08 & 0,02 & 0,00 & 0,00 & 0,00 \\
\hline
\end{tabular}


The Romanian Government approved Romania's Industrial Policy Plan up to 2008 and an economic action plan for the years 2006-2007 which comprise the action guidelines for the development of Romania's industry along European Union compatibility lines. They are in conformity with the pledges taken by Romania during her accession talks, laying emphasis on the implementation by the local business operators of the harmonized European legislation, as well as on the support programmes carried out by the authorities in keeping with the norms of the legislation for state-granted aid.

Romania's industrial policy relies on the following objectives: increasing competitiveness of Romania's industry that will enable the development of a market economy able to cope with competition in the single European market; increasing the part of research, development and innovation; promoting sustainable resource management and environmental protection, as well as improving professional training and employment. The processing industry is the main component of Romania's overall industry, having contributed 80 percent of the country's industrial output in 2004 . The basic segments of the processing industry are the metallurgy (27 percent), consumer goods ( 26 percent), chemicals and petrochemicals (20 percent), machine building (11 percent) and electronics and electric devices (4 percent). Approximately 1.5 million people work in these sectors. Statistics indicate that the sectors where high added-value products are produced have a relatively small share in Romania's industry, whereas energy-consuming industries have the greatest share.

There are three aims in view as far as the implementation of the new industrial policy is concerned: drawing up a calendar of measures and actions that will put into practice the provisions in the industrial policy plan; staging these measures and actions in the medium term; improving the institutional framework for industrial management and monitoring. The principal performance indicators to be measured are the industrial output, the volume of imports and exports, the investment volume, labor productivity, profitability, innovation and the number of employees.

\section{References}

Banai-Kashani, R., A New Method for Site Suitability Analysis: the Analytic Hierarchy Process, "Environmental Management", vol. 13, no 6, November 1989, Springer New York.

Kangas A., Leskinen P., Kangas J., Comparison of Fuzzy and Statistical Approaches in Multicriteria Decisionmaking, "Forest Science", 2007 no. 53.

Leskinen P., Kangas J., Rank Reversals in Multi-Criteria Decision Analysis with Statistical Modelling of Ratio-Scale Pairwise Comparisons, "Journal of the Operational Research Society" 2005 no. 56.

Leskinen P., Kangas A.S., Kangas J., Rank-based Modelling of Preferences in Multicriteria Decision Making, "European Journal of Operational Research” 2004 no. 158.

Pack H., Industrial Policy: Growth Elixir or Poison?, World Bank Research, Observer, vol. 15, no. $1,2000$.

Peneder M., Entrepreneurial Competition and Industrial Location, Edward Elgar, 2001. 
Porter M.E., The Competitive Advantage of Nations, The Free Press, New York 1990.

Rondinelli D., Applied Methods of Regional Analysis: the Spatial Dimensions of Development Policy, "Geographical Review", vol. 76, no 1, January 1996.

Russu C., Industrial Policy in Romania. Comunitary Experiences and Imperatives for Romanian Industry", Oeconomica, 2001 no. 4 (II).

Stiglitz J.E., Walsh C.E., Problems in Production Measurements in Economy, Economic Publishing House, Bucharest 2005.

Ţiţan E., Statistics. Theory and Applications in Tertiary Sector, Meteor Publishing House, Bucharest 2002.

Methodology of Short-term Business Statistics, Office for Official Publications of the European Communities, Luxembourg, European Communities, EUROSTAT, 2006 Edition.

European Comission Country Report 2003, European Comission Delegation in Romania, European Union, Bucharest, 2003, November the $5^{\text {th }}$.

Statistical Yearbook of Romania, National Institute of Statistics, 2005, 2006.

\section{Podaż produktów przemysłowych w Rumunii. Podejście terytorialne}

\section{Streszczenie}

W artykule, na podstawie zebranego materiatu statystycznego $z 2005$ r. zostata oceniona wielkość produkcji sektora przemystu $w$ Rumunii $i$ jej mikroregionach. W pierwszej części opisano wskaźniki statystyczne opisujace rynek produkcji przemysłowej w krajach Unii Europejskiej. Druga część jest poświęcona ocenie przemian $w$ rumuńskiej polityce ekonomicznej na rynku produktów przemystowych $w$ kontekście dążenia do wzrostu konkurencyjności kraju poprzez zmiany $w$ zakresie alokacji zasobów pomiędzy sektorami gospodarki i między regionami. Analizie tej przyświeca pytanie problemowe, czy zmiany zachodzace $w$ Rumunii mają szanse stać się częścia szerszych zmian we wspólnej polityce przemystowej krajów Unii Europejskiej. 